\title{
Spatial analysis including interpolation techniques for holistic groundwater monitoring and management
}

\author{
Bund Ulhas $\mathbf{T}^{1}$, Dube Y.A ${ }^{1}$, Katpatal Y.B ${ }^{2}$ \\ GSDA, Maharashtra, India ${ }^{1}$ \\ Visvesvaraya National Institute of Technology, Nagpur, Maharashtra, India ${ }^{2}$
}

\begin{abstract}
Ground water and surface water belong to the same hydrologic cycle and are inter-dependent. It is appropriate to consider these two sources together to work out the total water resources. The fact is that groundwater and surface water typically are in hydraulic continuity forming parts of a single system. There is thus growing awareness about the simultaneous development of surface water and groundwater, need to manage aquifer and the necessity for artificial recharge. Joint operation of the surface water and ground water system would require systematic management on basin and watershed levels. This in turn requires an understanding of the ground water system, its responses to the stresses imposed upon it and an understanding of the water resource utilization. The primary requirement in the simultaneous development of the surface and groundwater management is the inventory of water and land resources. This is prerequisite for quantitative and qualitative assessment of both the ground water and surface water resource development. Long time mean annual rate of recharge limits the potential ground water resource. It is important to appreciate the interrelated and independent nature of surface and ground water. Spatial analyses including interpolation techniques have potential for monitoring and representation of groundwater resource in any area.
\end{abstract}

Keywords: Holistic approach, water management, water resources.

\section{HOLISTIC APPROACH ON GROUND WATER MANAGEMENT}

Increased agricultural production and domestic demand would call for maximizing water resource utilization while minimizing expenditure. This is possible by restoring to integrated development of water resources for which a plan for coordinated and harmonious development of both surface as well as ground waters has to be undertaken.

Two different aquifer systems occur generally in all water basins; Shallow aquifers, which are readily recharged from surface like the phreatic aquifers and deep confined aquifer, which are generally tapped by bore wells and tube wells, which may not receive natural recharge from the area where groundwater development is planned.

The traditional assumption and definition of groundwater management means its controlled use according to some pre-determined plan. Unplanned and indefinite exploitation of ground water is observed assuming it to be freely available, and generally self - renewable resource. However, the recharge sometimes is so slow or even so small that natural replenishment does not occur within the period that is relevant to current planning and management. In some areas ground water from the underlying water bearing formation is being pumped out at a rate faster than the rate of its natural replenishment. Such area experience declining trends of ground water levels due to overdraft. Whether this situation is unwise or otherwise is not merely a point of view but is dependent on several aspects which are required to be considered in terms of benefits accrued, and the extent to which it is feasible.Nearly all aspects of development and urbanization indicate continuing and growing need for use of ground water in developing the economy of the every region. When ground water mining becomes a indefinite

phenomenon it results in consuming the stored up ground water, progressively lowering the ground water levels. When groundwater withdrawals exceeds annual groundwater recharge, the groundwater management comes into play and becomes vital. The groundwater regimes are different in the cases of confined and unconfined aquifers. Unconfined aquifers, which receive direct recharge from rainfall infiltration or influent seepage from rivers may be developed up to the limit of annual increment. Such aquifers are neither of large extent or thickness in greater parts of the peninsular India. In certain areas the rivers are influent to the water table-aquifers losing thereby, considered amount of their flows (Charlu, 1982). Scientific management of ground water would therefore call for a balance between average annual replenishment and average annual extraction. Under conditions of optimum development considerable water table fluctuations may occur. In periods of successive subnormal rainfall, steady ground water pumpage may remove ground water from storage resulting in decline in ground water levels. During periods of above normal rainfall, when the recharge to the ground water storage is in excess of the withdrawals in the series of wet years, these ground water levels will rise up. Remote Sensing and Geographical Information System (GIS) are vital for understanding the groundwater surface water interaction and change in status of groundwater. Many workers ( Krishnamurthy et al., 2000; Katpatal, 1997; Obireddy and Maji, 2003; Katpatal and Dube, 2003, 2010; Shrivastava et al, 2004; Katpatal and Chavan, 2012) have used remotely sensed data and GIS for studying various aspects of groundwater analysis and status representation. 


\section{BASIC PREREQUISITES TO THE \\ MANAGEMENT PLAN}

The drafting of the management plan for surface and groundwater resource development on a regional scale, which in this study has been presumed to be interrelated domains and it is presumed that simultaneous development of the two is inevitable, calls for certain prerequisites which are discussed below. These can be treated as the preliminary steps in the designing of the regional management plan of the water resources of any region.

1) The understanding of rainfall intensity and pattern: The rainfall intensities and pattern forms the basis of the development of water resources in any area. More scarce this commodity would be in any region, more stringent management plan has to be adopted by the region.

2) Understanding the Runoff pattern: The rainfall intensities and the patterns in turn decide the runoff process and the time distribution of runoff. The runoff process in the area and its duration are important factors in resources planing and design. Mathematical modeling is extensively used to simulate the rainfall-runoff record. However, it is generally not possible to calibrate and validate these event-based models for most of the catchments and hence indirect methods as proposed in this study have to be adopted.

3) The relationship between geomorphological characteristics and the hydrogeological variables are next to be thoroughly understood. These serve a useful tool to determine the hydrologic response of the basin. Geomorphological units directly give information about the hydrogeological characteristics, which can be quantified using techniques like GIS, well supported by the well data. This adds a new dimension to hydrological studies.

4) Identification of the surface and Groundwater potential: Sufficient information about the surface and groundwater potential is must to delineate the reservoir capacity and the site suitability for surface water storage.

5) Identification and demarcation of the recharge, runoff and storage areas: The classification of the spatial domain on the regional scale into potential recharge areas, the runoff areas and the potential storage areas helps in selection of the suitable developmental strategies and adoption of a efficient management plan.

6) Groundwater level fluctuation: Groundwater fluctuations are calculated from the groundwater levels recorded through monitoring. Groundwater fluctuations display important information about the aquifer characteristics and the dynamic behavior of the aquifer within the area. Some of the parameters, which are difficult to be modeled in the heterogeneous and complex aquifer system, can be extracted by understanding the water level fluctuation within the area.

7) Long term groundwater trend: A long term analysis not only indicates about the natural recharge scenario but also draw downs which are existing in various areas and which are very difficult to be obtained. Hence, the longterm trends have to be considered in any management plans.

8) Observation of the surface water bodies and their temporal variation: The surface water bodies and the changes within their dimension is also important for understanding the characteristics of the recharge phenomenon and for selecting the site suitability of surface water resource development.

\section{INTEGRATED WATER RESOURCES MANAGEMENT IN BHANDARA DISTRICT}

The most striking feature in Bhandara District, which plays a very important role in designing of the water resources management plan for the district is presence of a considerably thick weathering zone in most of the areas. This is seen as a supportive as well as degenerative parameter for the water resource development within the district. The justification of considering the weathered zone both a supportive as well as degenerative parameter may be given in two steps, one each for its supportive and degenerative role:

Weathering zone acts as a venue for the groundwater storage in case of the shallow aquifers in absence of the inherited porosity in the hard rock terrain. It also acts as conduits for groundwater migration. The considerable thickness of weathered zone and its exposure on the surface enhances the interception of the runoff increasing the recharge. The weathering zone is covered by a thin uppermost layer, which is found to be fine grained clays which are generally formed from the in situ mineral alterations of the feldspars present in most of the metamorphosed rocks or by silting process when transported to other places. This thin clay layer which is seen to bear impervious characteristics is generally present over all the rock formations invariably covering vast areas. This retards the natural recharge even over a thick weathered zone and acts as a degenerative factor for the groundwater recharge.

\section{Groundwater fluctuations and long term trend:}

As already discussed the fluctuation in the ground water and the variations within long duration given, as trends are important parameters to understand the localised changes within the area. In Bhandara district, it has been observed that relationship between the ground water fluctuations, long term trends and the lithounits can be identified. It is interesting to note that the deeper groundwater levels (around $15 \mathrm{~m}$ ) are typically associated with the litho types like phyllites, granitic gneisses and mica schist at various places on one side where as increase in trends is observed in Some of these lithologies.

Similarly the lithounits like sandstone and alluvium are also showing deeper water table levels and decline at some of the places. Shallow water tables are identified in the areas with high lineament density and gentle slopes, while increase in water level trends is observed in areas of moderate to gentle slopes. It means that the areas having good ground water potential lithology wise are some times not utilized to their full capacity or the base flow towards the rivers flowing adjacent to these formations is occurring. This is typically evident in the region of mica schist and granitic gneisses which are showing decline, which are feeding through base flow to the river system or to the alluviums adjacent to them, which shows increase in trend. 
However, some alluvial patches are also showing decline along with sharp decline in granitic gneisses, which must be due to over irrigation from groundwater. Hence it is realized that observation of ground water levels (GSDA, 2002), their seasonal fluctuation and the water level trends have to be understood in proper light of associated parameters. Therefore to accurately assess contribution of all the parameters, it is necessary to understand the dynamic behavior of the aquifer system, which requires modelling of all the parameters for fixing priorities.

The water table ( CGWB, 1984;1995;1997) representing the ground water reservoir level and changes in its level represented by the fluctuation has been thoroughly studied for Bhandara district ( Table 1). The map showing average fluctuation in groundwater level for the period 1998 to 2003 has been given in Figure No.1. The seasonal fluctuations do not depict the true picture of the draw down and long term recharge. Hence, the maps showing the rise or fall of the water table for the period 1993-2003 have been prepared separately for pre-monsoon and post monsoon and have been given as Figure Nos.2 and 3. The specific information related to the time dependent changes in water levels in wells could be depicted by hydrographs, which are presented for some of the wells selected from different parametric categories like lithologies, slopes (Figure No. 4-6).

\begin{tabular}{|c|c|c|c|c|c|c|c|c|c|}
\hline $\begin{array}{l}\text { Well } \\
\text { No. }\end{array}$ & Village & Taluka & $\begin{array}{c}\text { Fluctuation } \\
98\end{array}$ & $\begin{array}{c}\text { Fluctuation } \\
\quad 99\end{array}$ & $\begin{array}{c}\text { Fluctuation } \\
00\end{array}$ & $\begin{array}{c}\text { Fluctuation } \\
01\end{array}$ & \begin{tabular}{|c} 
Fluctuation \\
02
\end{tabular} & $\begin{array}{c}\text { Fluctuation } \\
03\end{array}$ & $\begin{array}{c}\text { Average } \\
\text { fluctuation } \\
(1998-2003)\end{array}$ \\
\hline B 2 & Dhargaon & Bhandara & 4.75 & 7.30 & 4.10 & 7.40 & 7.20 & 8.60 & 6.558 \\
\hline B 3 & Dodmazhari & Bhandara & 2.25 & 2.90 & 4.70 & 4.55 & 5.80 & 6.60 & 4.467 \\
\hline B 4 & Fulmogra & Bhandara & 1.17 & 6.20 & 3.50 & 8.50 & 7.90 & 5.35 & 5.437 \\
\hline B 5 & Kardha & Bhandara & 7.25 & 7.58 & 5.40 & 6.50 & 8.40 & 9.80 & 7.488 \\
\hline B 6 & Kharbi & Bhandara & 3.24 & 7.53 & 3.40 & 3.20 & 4.20 & 4.90 & 4.412 \\
\hline B 7 & Kondhi & Bhandara & 0.74 & 1.00 & 0.80 & 0.50 & -0.60 & 10.00 & 2.073 \\
\hline B 8 & Maudi & Bhandara & 4.30 & 5.09 & 3.20 & 4.70 & 5.00 & 5.50 & 4.632 \\
\hline B 9 & Pahela & Bhandara & 2.96 & 4.55 & 4.40 & 4.40 & 4.70 & 7.20 & 4.702 \\
\hline B 11 & Pindkepar & Bhandara & 1.26 & 5.04 & -0.70 & -2.30 & -1.30 & -0.60 & 0.233 \\
\hline B 10 & Parsodi & Bhandara & 2.40 & 2.75 & 2.45 & 3.70 & 5.80 & 7.20 & 4.050 \\
\hline B 12 & \begin{tabular}{|l} 
Pipri \\
\end{tabular} & Bhandara & 2.84 & 4.36 & 1.00 & 1.60 & 3.00 & 2.65 & 2.575 \\
\hline B 14 & Chichal & Lakhandur & 0.00 & 0.00 & 0.00 & 0.00 & 0.00 & 0.00 & 0.000 \\
\hline B 13 & Bhadgi & Lakhandur & 2.91 & 4.00 & 2.50 & 2.00 & 1.80 & 2.80 & 2.668 \\
\hline $\bar{B} 15$ & Dahegaon & Lakhandur & -0.43 & 7.40 & 5.50 & 6.35 & 6.10 & 8.50 & 5.570 \\
\hline B 16 & Dighori & Lakhandur & 2.52 & 6.90 & 5.30 & 3.40 & 3.70 & 7.80 & 4.937 \\
\hline B 17 & Lakhandur & Lakhandur & -0.04 & 5.63 & 2.30 & 5.05 & 6.20 & 6.15 & 4.215 \\
\hline $\bar{B} 18$ & Palandur & Lakhani & 5.45 & 7.30 & 6.05 & 6.85 & 7.60 & 9.20 & 7.075 \\
\hline $\bar{B} 19$ & Soni & Lakhandur & -2.43 & -2.36 & 5.20 & 4.50 & 6.50 & 6.75 & 3.027 \\
\hline B 20 & Andhalgaon & Mohadi & 1.45 & 1.22 & 1.50 & 1.50 & 2.10 & 4.55 & 2.053 \\
\hline B 21 & Bachera & Mohadi & 1.00 & 3.48 & 1.30 & 2.60 & 2.70 & 6.45 & 2.922 \\
\hline B 22 & Chichkheda & Mohadi & 0.00 & 0.00 & 0.00 & 0.00 & 0.00 & 0.00 & 0.000 \\
\hline B 23 & Dahegaon & Mohadi & 2.15 & 5.35 & 1.85 & -5.30 & -3.10 & 2.10 & 0.508 \\
\hline B 25 & Kandri & Mohadi & 1.05 & 1.45 & 0.70 & 2.30 & 1.50 & 2.50 & 1.583 \\
\hline B 24 & Devada BK. & Mohadi & 1.60 & 3.94 & 4.56 & 5.40 & 6.00 & 7.60 & 4.850 \\
\hline B 26 & Kardi & Mohadi & 1.85 & 3.05 & 3.30 & 3.50 & 4.00 & 3.40 & 3.183 \\
\hline B 29 & Mohadi & Mohadi & 0.50 & 0.97 & 1.40 & 4.80 & 8.40 & 3.80 & 3.312 \\
\hline B 28 & Koka & Mohadi & 4.85 & 10.67 & 5.60 & 8.95 & 12.40 & 11.65 & 9.020 \\
\hline B 27 & Kohdgaon & Mohadi & 1.10 & 3.68 & 1.90 & 3.30 & 2.80 & 2.70 & 2.580 \\
\hline B 31 & Usarra & Mohadi & 3.60 & 6.71 & 6.55 & 6.05 & 10.40 & 9.90 & 7.202 \\
\hline B 30 & Satona & Mohadi & 1.00 & 0.10 & 0.95 & 10.25 & 9.00 & 5.70 & 4.500 \\
\hline B 32 & Warthi & Mohadi & 2.10 & 4.55 & 2.82 & 3.70 & 4.50 & 5.20 & 3.812 \\
\hline B 35 & Chandi & Paoni & 1.07 & 2.05 & 2.50 & 7.60 & 10.50 & 15.30 & 6.503 \\
\hline B 33 & Adyal & Paoni & 1.52 & 1.33 & 0.60 & 0.45 & 1.70 & 1.30 & 1.150 \\
\hline B 34 & Bhuyar & Paoni & 4.40 & 6.85 & 4.20 & 1.80 & 7.70 & 7.70 & 5.442 \\
\hline B 38 & Gosse BK. & Paoni & 3.42 & 2.51 & 2.35 & 2.80 & 2.30 & 6.40 & 3.297 \\
\hline B 36 & Channewada & Paoni & 2.83 & 5.80 & 4.00 & 3.70 & 6.20 & 9.70 & 5.372 \\
\hline B 37 & Dhamni & Paoni & 0.00 & 0.00 & 0.00 & 0.00 & 0.00 & 0.00 & 0.000 \\
\hline B 39 & Kanhalgaon & Paoni & 2.49 & 3.23 & -1.61 & 3.40 & 5.70 & 10.00 & 3.868 \\
\hline
\end{tabular}


International Advanced Research Journal in Science, Engineering and Technology Vol. 1, Issue 4, December 2014

\begin{tabular}{|c|c|c|c|c|c|c|c|c|c|}
\hline B 41 & Nilaj & Paoni & 3.07 & 3.50 & 4.15 & 4.10 & 6.20 & 13.05 & 5.678 \\
\hline B 40 & Kondha & Paoni & 0.00 & 0.00 & 0.00 & 0.00 & 0.00 & 0.00 & 0.000 \\
\hline B 43 & Pawni & Paoni & 2.20 & 2.33 & 2.15 & 2.00 & 3.90 & 9.90 & 3.747 \\
\hline B 42 & Palora & Paoni & 0.50 & 0.50 & -3.30 & 0.70 & 0.00 & 0.00 & -0.267 \\
\hline B 46 & Wahi & Paoni & 3.92 & 8.30 & 5.70 & 6.80 & 8.70 & 12.00 & 7.570 \\
\hline B 44 & Sindpuri & Paoni & 1.16 & 1.70 & 1.60 & 2.40 & 2.80 & 3.60 & 2.210 \\
\hline B 45 & Thana & Paoni & 2.55 & 2.23 & 3.80 & 2.80 & 3.20 & 3.50 & 3.013 \\
\hline B 47 & Bampewada & Sakoli & 3.45 & 10.85 & 6.50 & 8.80 & 8.60 & 13.30 & 8.583 \\
\hline B 48 & Bhugaon & Sakoli & 3.50 & 5.35 & 1.55 & 4.40 & 5.80 & -0.70 & 3.317 \\
\hline B 50 & Dongargaon & Lakhani & 1.60 & 3.25 & 7.10 & 3.00 & 4.50 & 4.70 & 4.025 \\
\hline B 49 & Bodra & Sakoli & 2.75 & 2.20 & 3.40 & 3.70 & 5.20 & 6.20 & 3.908 \\
\hline B 51 & Jamnapur & Sakoli & 4.55 & 9.40 & 4.00 & 7.30 & 7.90 & 13.00 & 7.692 \\
\hline B 53 & Khandala & Sakoli & 5.05 & 5.55 & 3.40 & 4.80 & 5.20 & 9.95 & 5.658 \\
\hline B 54 & Kumbli & Sakoli & 2.95 & 5.65 & 1.35 & 3.70 & 4.00 & 13.85 & 5.250 \\
\hline B 52 & Kesalwada & Lakhani & 2.80 & 8.00 & 3.55 & 6.40 & 6.60 & 6.50 & 5.642 \\
\hline B 55 & Lakhani & Lakhani & 2.40 & 5.80 & 3.55 & 4.50 & 5.50 & 9.25 & 5.167 \\
\hline B 56 & Mundipar & Lakhni & 2.90 & 5.05 & 4.70 & 4.50 & 5.30 & 7.10 & 4.925 \\
\hline B 57 & Parsodi & Sakoli & 2.20 & 5.05 & 3.55 & 2.00 & 9.60 & 8.80 & 5.200 \\
\hline B 58 & Sakoli & Sakoli & 1.90 & 3.70 & 8.90 & 7.20 & 9.50 & 13.90 & 7.517 \\
\hline B 59 & Salebhata & Lakhani & 1.30 & 2.50 & -0.10 & 2.30 & 2.00 & 3.25 & 1.875 \\
\hline B 60 & Sangaon & Sakoli & 0.00 & 0.00 & 0.00 & 0.00 & 0.00 & 0.00 & 0.000 \\
\hline B 64 & Chikhli & Tumsar & 2.20 & 3.60 & 2.45 & 4.70 & 7.65 & 9.20 & 4.967 \\
\hline B 63 & Chargaon & Tumsar & 1.65 & 2.50 & -0.30 & 2.20 & 2.80 & 12.50 & 3.558 \\
\hline B 62 & Bagheda & Tumsar & 3.60 & 5.35 & 1.80 & 3.90 & 4.80 & 6.10 & 4.258 \\
\hline B 65 & Chicholi & Tumsar & 3.70 & 5.93 & 7.48 & 6.60 & 5.60 & 5.20 & 5.752 \\
\hline B 66 & Gobarwahi & Tumsar & 4.00 & 1.95 & 1.50 & -0.40 & 6.00 & 5.80 & 3.142 \\
\hline B 67 & Khapa & Tumsar & 1.35 & 4.05 & 2.77 & 4.60 & 4.30 & 7.55 & 4.103 \\
\hline B 69 & Lendezari & Tumsar & 2.45 & 3.30 & -1.40 & 3.80 & 4.05 & 4.75 & 2.825 \\
\hline B 61 & Asthi & Tumsar & 0.90 & 1.95 & 1.70 & 1.95 & 2.90 & 4.25 & 2.275 \\
\hline B 68 & Koshti & Tumsar & 2.75 & 3.28 & 2.20 & 1.60 & 2.40 & 4.15 & 2.730 \\
\hline B 72 & Rajapur & Tumsar & 1.25 & 2.80 & 3.00 & 3.85 & 4.80 & 7.05 & 3.792 \\
\hline B 71 & Paonarkhari & Tumsar & 2.95 & 7.25 & 5.80 & 6.55 & 5.50 & 8.35 & 6.067 \\
\hline B 70 & Mangli & Tumsar & 2.10 & 5.32 & 5.55 & 6.45 & 6.40 & 6.80 & 5.437 \\
\hline B 73 & Tudka & Tumsar & 0.00 & 2.90 & 5.55 & 1.10 & 4.70 & 8.30 & 3.758 \\
\hline B 74 & Kharbi & Tumsar & 3.05 & 4.30 & 2.00 & 2.10 & 3.50 & 5.70 & 3.442 \\
\hline B 1 & Bhandara & Bhandara & 2.65 & 4.00 & 3.30 & 0.70 & 2.20 & 3.10 & 2.658 \\
\hline G 1 & Jamb & Mohadi & 3.75 & 4.90 & 3.42 & 5.07 & 7.20 & 8.70 & 5.507 \\
\hline G 2 & Palari & Bhandara & 3.60 & 5.50 & 3.72 & 7.14 & 5.30 & 7.80 & 5.510 \\
\hline G 3 & Daodipar & Bhandara & 4.75 & 4.90 & 5.57 & 4.97 & 7.30 & 8.37 & 5.977 \\
\hline G 4 & Pitjhari & Sakoli & 5.10 & 6.15 & 4.48 & 5.88 & 3.55 & 5.27 & 5.072 \\
\hline G 5 & Ekodi & Sakoli & 1.20 & 3.30 & 1.63 & 4.60 & 3.45 & 7.23 & 3.568 \\
\hline G 8 & Varti & Mohadi & 2.05 & 2.50 & 3.06 & 3.39 & 2.60 & 3.01 & 2.768 \\
\hline G 6 & Sihora & Tumsar & 5.10 & 5.90 & 7.95 & 9.43 & 9.50 & 9.22 & 7.850 \\
\hline G 7 & Madgi & Bhandara & 4.40 & 4.20 & 3.57 & 4.98 & 3.95 & 5.98 & 4.513 \\
\hline G9 9 & Sakra & Sakoli & 5.80 & 5.97 & 0.34 & 4.82 & 7.35 & 10.00 & 5.713 \\
\hline
\end{tabular}

Table no 1: water level fluctuation (1998-2003) 


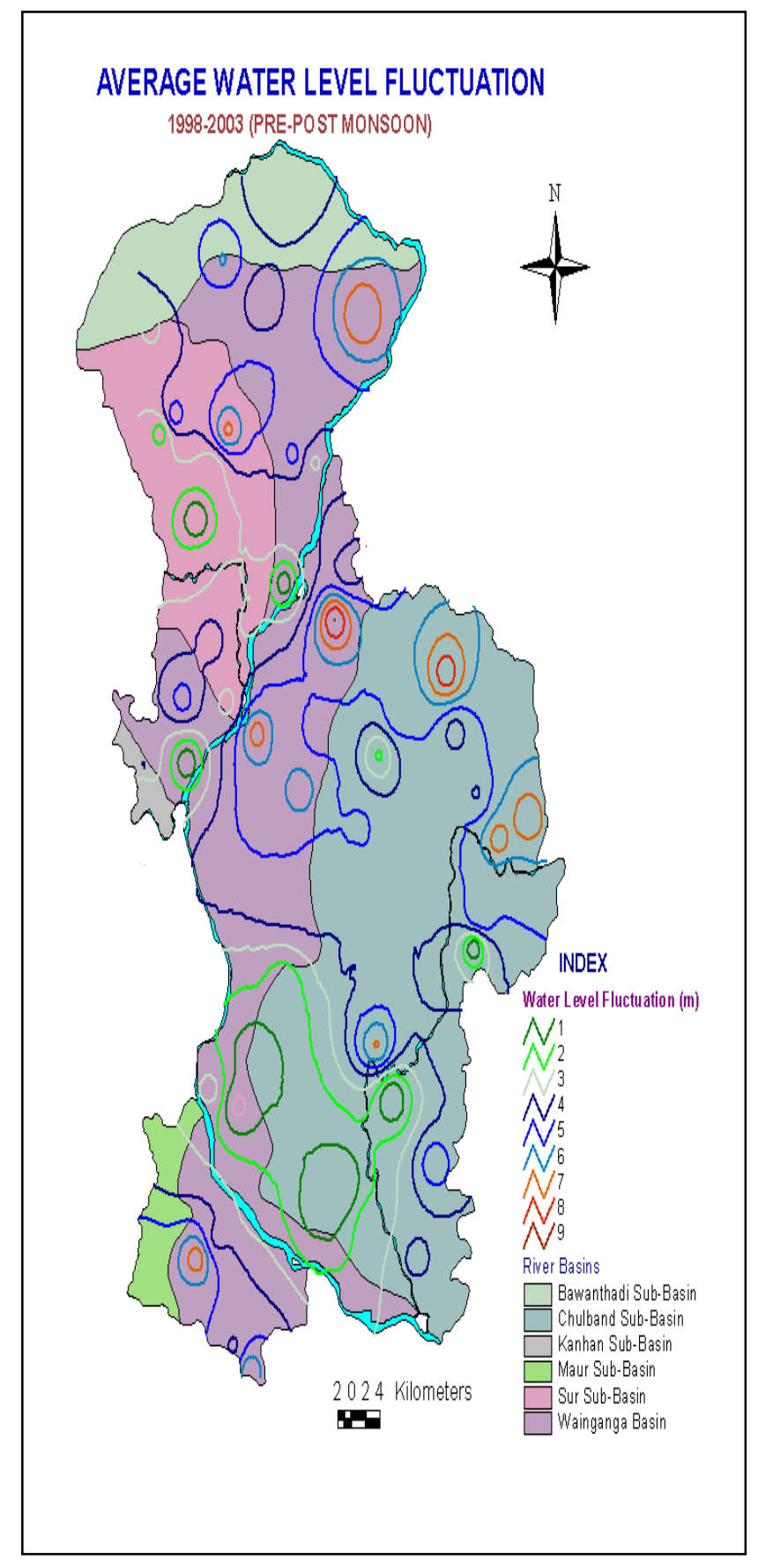

Fig. No. 1

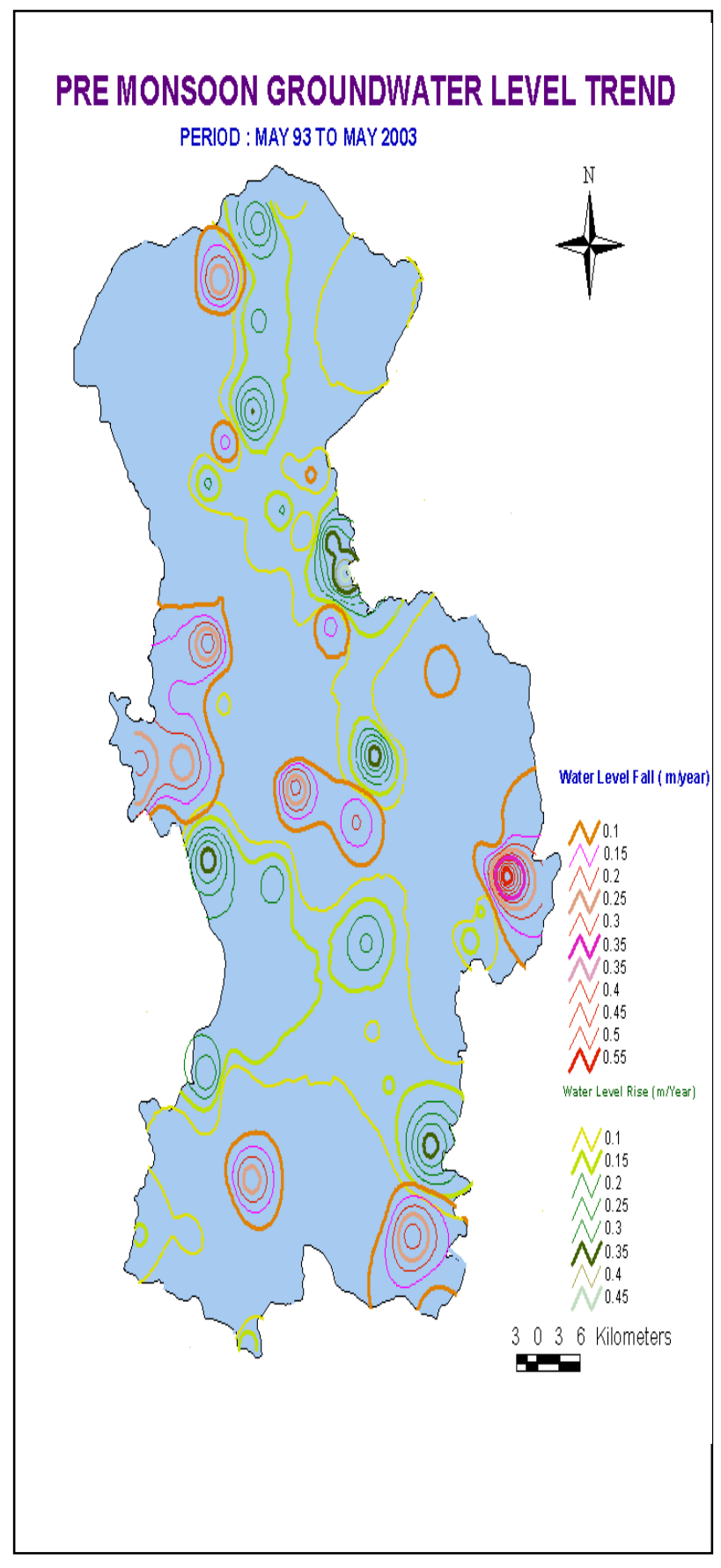

Fig. No. 2 


\section{POST MONSOON GROUNDWATER LEVEL TREND}

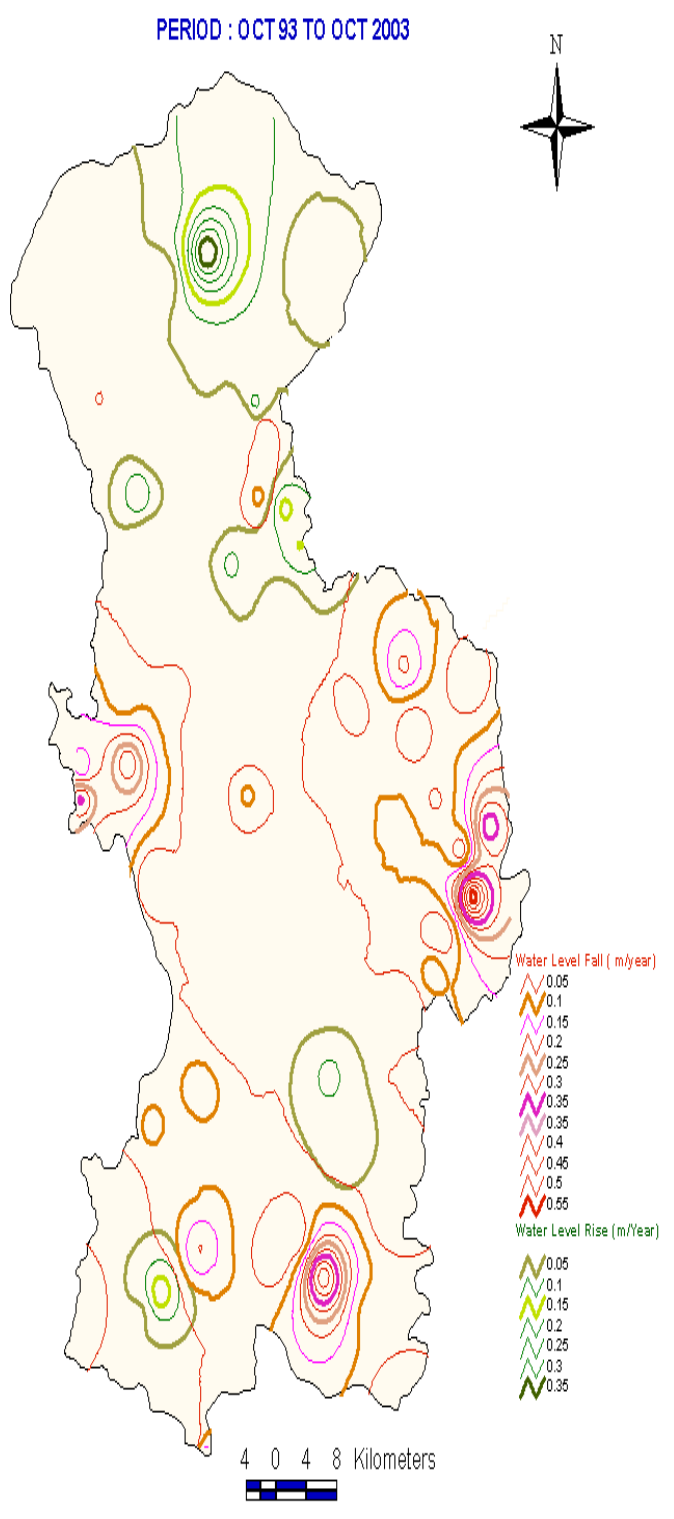

Fig. No. 3

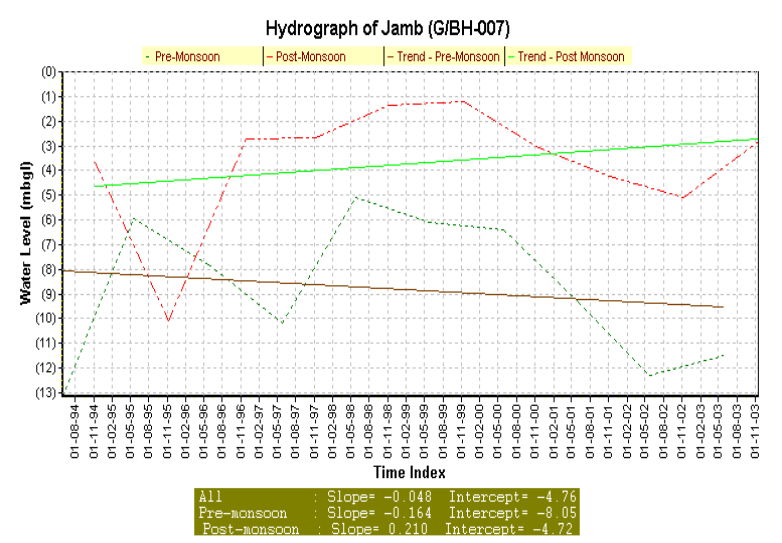

Fig. No. 4

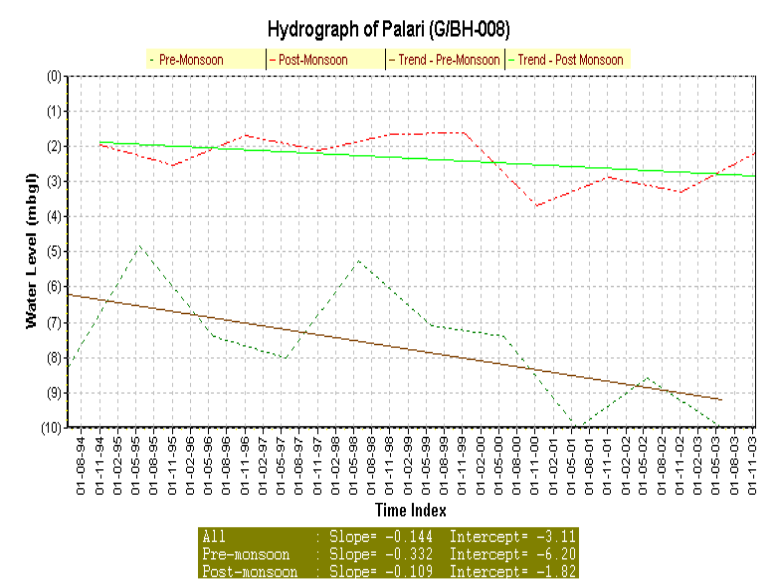

Fig. No. 5

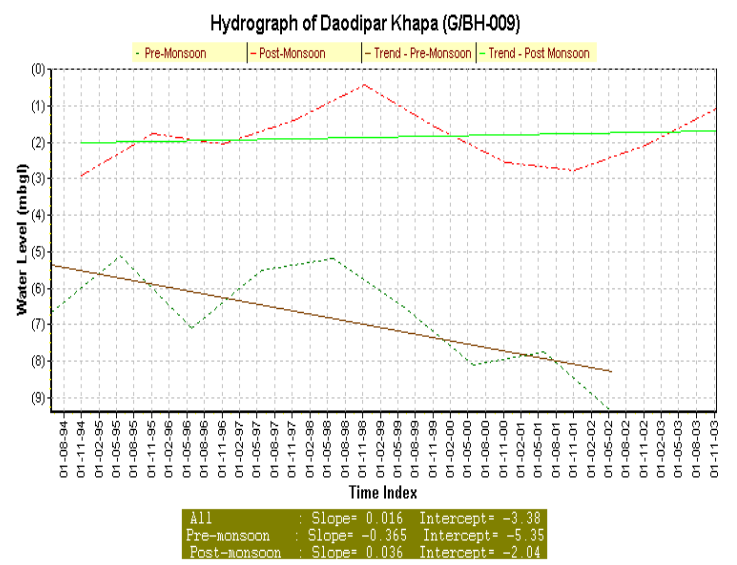

Fig. No. 6

\section{Recharge, runoff and storage zones:}

Areas can be delineated into recharge and discharge areas depending on whether water is added to or abstracted from the zone of saturation. In the case of the water-table aquifer, usually the areas occupying higher elevation with deeper water tables constitute recharge areas while the topographic lows with shallow water tables comprise natural discharge areas or the storage zone. Between these two extremes lies an intermediate transit zone, also refereed to be as the runoff zone, characterized by the existence of recharge condition in some part of the year and discharge condition in others.

In Bhandara district the recharge, runoff and storage zones have been demarcated on the basis of slope classes and drainage orders \& patterns. The areas with high slope and high frequency of first order drainage have been marked as runoff zones. The areas have been included under recharge zone, where slope is moderate and lower order of drainage is directly meeting, next to higher order drainage. The area where slope is very low and only higher order drainage is present has been taken as storage zone. The recharge, runoff and storage zones are shown in Figure No.7. The total area of recharge, discharge and storage zones are given in Table No.2. 
International Advanced Research Journal in Science, Engineering and Technology Vol. 1, Issue 4, December 2014

\begin{tabular}{|c|l|c|}
\hline Sr. No. & Zones & Area (Sq. Km.) \\
\hline 1 & Recharge Zone & 2449.7444 \\
\hline 2 & Runoff Zone & 1130.9221 \\
\hline 3 & Storage Zone & 509.6131 \\
\hline
\end{tabular}

Table No.2: Runoff, Recharge and storage zones

It has been recognized that the boundaries or even the classification of areas into recharge and discharge can not be rigid in view of the fact that the depth of the water table is variable. After a series of high rainfall years the lower fringes of recharge areas may convert slightly into discharge areas. And the areas, which have been classified, as recharge areas become discharge areas due to surfacewater irrigation and consequent rise in the water table to near-surface levels after the recharge practices have been operated for longer duration. Extensive ground-water development has turned many discharge areas into areas of recharge due to the lowering of the water table as is evident in the areas of Chauras. Periodical delineation of these zones is a prerequisite for the precise estimation of the ground-water resource.

\section{RUNOFF, RECHARGE AND STORAGE ZONES ON THE BASIS OF GEOMORPHOLOGY, DRAINAGE ORDER AND SLOPE}

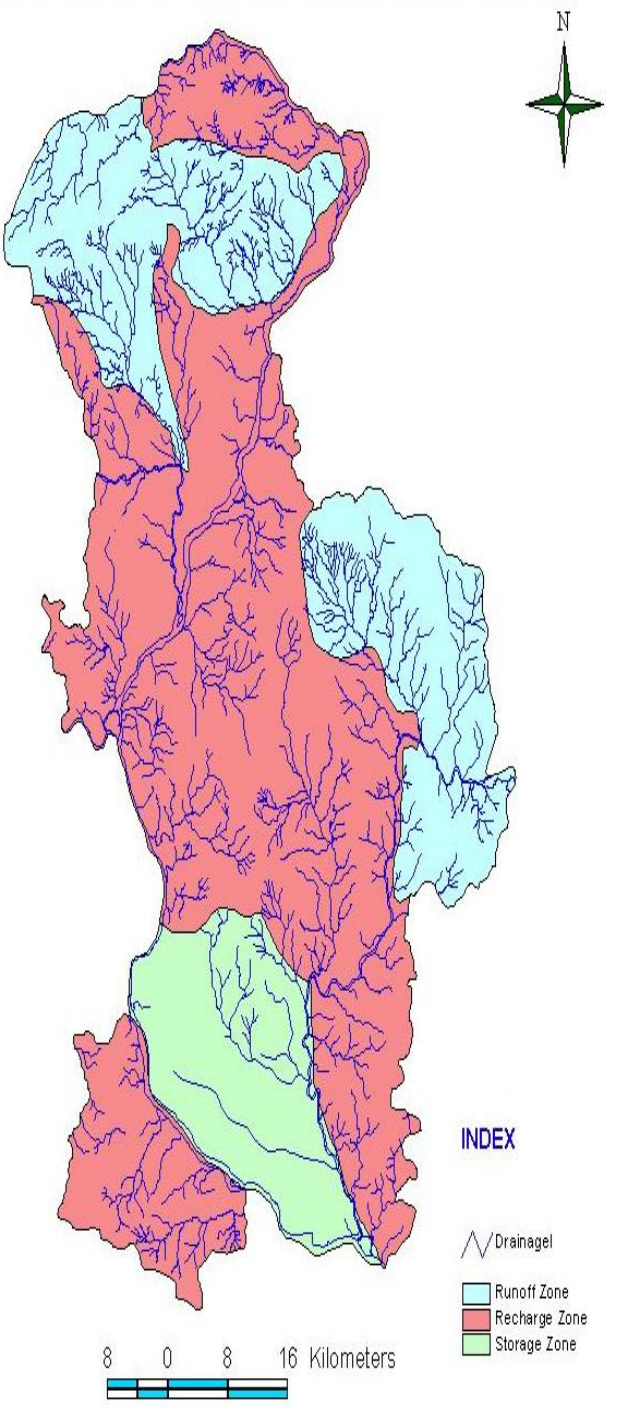

Fig. No.7

\section{GENERAL GUIDELINES BASED ON THE RESULTS OBTAINED}

- Bhandara District has a peculiar feature of presence of large number of water bodies. These water bodies are present in the specific areas, which show low amount of surface percolation. These regions show low infiltration due to thin clay/silt deposition in these areas where the frequency of smaller ponds is high. It is hence suggested that simultaneous practice of development of the existing pond in conjunction with the recharge well situated in the close vicinity may be taken up and the surplus intake in the pond during monsoon should be directed into the well as direct injection. Similar charging may also be practiced for the bore wells present in the vicinity. This will also solve the problem of silting which is generally observed when special structures for the injection are designed since the ponds can tackle the silt which would go as deposition within it and the water can be directly put into the aquifer.

- The case would be slightly different in the recharging from the streams which would yield high amount of silts which would be deposited either on the arrest structures or would directly go into the recharge well due to almost no time provided for the settling in the streams. Here, it is proposed to construct separate structure to act as filter well and recharge well available adjacently.

- The areas in the close vicinity of the rivers should be avoided for injection and here base flow should be arrested through construction of dykes or underground bandharas.

- The practice of 'pond rotation' can be adopted in the area, which proposes construction of farm ponds for shorter duration, which can later be converted into paddy cultivation areas.

- A new structure is proposed especially for the area, which may be experimented. This structure envisages use of slotted, curved, pre-fabricated compartments used within the lining of the dug wells which would enhance the recharge in the horizontal section during the monsoon season which requires faster transmission during recharge. - To increase the yield potentials, horizontal slotted pipes may be used ahead of the arrest structures to get improved supplies.

\section{REFERENCES}

CGWB, CR, Nagpur (1984) Report on the "Systematic Hydrogeological studies in parts of Nagpur and Bhandara districts of Maharashtra and Seoni districts of Madhya Pradesh".

CGWB, (1995), Groundwater resources \& development potential of Bhandara District, Maharashtra, Annual Action Program, 654 / DIS/95, 1993-94

CGWB( 1997 ) Ministry of Water Resources, Govt. of India. Report on Ground Water Resource Estimation Methodology-1997 (GEC-1997) New Delhi, June 1997.

Charlu, T.G.K., (1982), Groundwater Development in India. Published by rural electrification Corporation Ltd., New Delhi.

GSDA (2002), Historical Data, under systematic hydrological surveys (since commencement upto 31/3/2002, District Bhandara

Katpatal, Y.B., (1997), Overlaying carrying capacity parameters for impact assessment studies through Remote Sensing. International Conference on Engineering Geology and Environment, Athens, Greece, pp. $1293-1298$

Katpatal, Y.B., Dube, Y.A., (2003), Pioli watershed health assessment through Remote Sensing and GIS, National conference on Integrated Sustainable Water resource Planning and Management, organized by Department of civil Engineering, Birla Institute of Technology and Science, Pilani, pp. 190-195. 
Katpatal Y. B, Chavan C. S (2012), 'Study of groundwater level profile in an unconfined aquifer: Case study of Nagpur urban area, Central India' ; International Journal of Civil, Engineering (IJCE), ISSN: 2278-9987, Vol.1, Issue 2, Nov 2012 pp 25-33, (C) IASET. International Journal of Civil Engineering ( IJCE );ISSN(Print): 2278-9987; Impact Factor(JCC): 2.6676

Katpatal Yashwant B., Dube Y.A., (2010) Comparative Overlay Analysis through Analytical Hierarchical Process to Delineate Groundwater Potential Zones Using Satellite Data, International Journal of Earth Sciences and Engineering, ISSN 0974-5904 Volume 3, No. 5,October 2010, 638-653.

Krishnamurthy, Jagannathan Mani, Arul, Jayaraman V., Manivel M., (2000), Groundwater resource development in hard rock terrain: An approach using Remote Sensing and GIS Techniques. International Journal of applied earth observation and geoinformation, Vol. 2, Issue3/4, 2000, pp. 204-215.

Obireddy, G.P., Maji, A.K., (2003), Delineation and characterization of geomorphological features in a part of lower Maharashtra metamorphic plateau using IRS-ID LISS III data. Journal of the Indian Society of Remote Sensing, Vol. 31, No.4, pp. 241-251.

Shrivastava, P.K., Tripathi, M.P., Das, S.N., (2004), Hydrogeological modelling of small watersheds using satellite data and GIS technique. Journal of the Indian Society of Remote Sensing, Vol. 32, No.2, pp. 145157. 